\title{
ROKYTNÁ: NON-INVASIVE RESEARCH INTO THE SETTLEMENT STRUCTURE OF AN EARLY MEDIEVAL CENTRE
}

\author{
PETER MILO - JAN HAVELKA
}

\begin{abstract}
Research into central places is one of the most attractive themes in archaeological investigation and includes early medieval strongholds that reflect the political and socio-economic changes of their time. Archaeological research within the territory of Moravia (the eastern half of the Czech Republic) has long tended to concentrate on resolving issues of the centres of power related to the existence of the Moravian principality in the 9th-10th century, while sites linked to the building of the Premyslid domain in the 11th-12th century have been investigated to a lesser extent. This contribution presents the results of research into the hillfort of Rokytná, which falls within this period. The hillfort, which is also known from period written sources, governed its own administrative district and enjoyed a prominent position among Premyslid centres in Moravia. New data on the characteristics and structure of settlement was acquired with the help of a combination of non-destructive survey methods. The principal method was a geophysical survey using the magnetometer, accompanied by archaeological fieldwalking. A comparison of the magnetometer prospection and the results of pedestrian survey indicated possible interpretational discrepancies. Despite these it was established that during the period of operation of this medieval centre the whole investigated area was densely inhabited. At the same time, it was established that the site had been disturbed by deep ploughing and the effects of erosion which heavily influenced the data.
\end{abstract}

Keywords: archaeological fieldwalking - geophysical survey-early medieval centre - settlement structure.

\section{Rokytná: nedestruktivní průzkum sídelní struktury raně š̌edověkého centra}

Abstrakt: Výzkum centrálních lokalit predstavuje v archeologickém bádání jedno z nejatraktivnějšich témat. Patři sem také raně středověká hradiska, která jsou odrazem politických a společensko-ekonomických změn své doby. Na území Moravy je archeologický výzkum dlouhodobě zaměrený spiše na řešení otázek mocenských center souvisejicich s Velkomoravskou ř́ši v 9.-10. století. Lokality spojené s budováním přmyslovské domény v 11.-12. století byly zkoumány v menši míre. Příspěvek přináši výsledky bádání na hradisku Rokytná, které spadá právě do tohoto obdobi. Toto hradisko, které je známé i z dobových písemných pramenů, spravovalo vlastni hradský obvod a mezi přemyslovskými centry na Morave zaujímalo přední postavení. Nové poznatky o charakteru a struktuře osidleni byly ziskány kombinaci nedestruktivních metod průzkumu. Stěžejní metodou byl geofyzikální průzkum pomocí magnetometru, který byl doplněn liniovými povrchovými sběry. Konfrontace magnetického průzkumu a výsledků povrchových sběrů ukázala na možné interpretačni disproporce. I pres to bylo zjištěno, že v obdobi fungování raně středověkého centra byla celá zkoumaná plocha intenzivně osídlena. Současně ale bylo konstatováno výrazné narušeni lokality hlubokou orbou a erozními procesy, které prvotní data výrazně ovlivnily.

Klíčová slova: povrchové sběry - geofyzikální průzkum - raně středověké centrum - sídlištní struktura.

\section{Introduction}

Moravia was annexed by Bohemia during the rule of Duke Oldřich (1012-1033 and 1034) and his son Břetislav (in Moravia probably from 1029 and in Bohemia 1034-1055), who took Moravia under his administration. This process went hand in hand with building an administrative system of strongholds to ensure the execution of Přemyslid princely power in Moravia. In the mid-11th century the elementary network of strongholds was completed and Moravia was divided into two administrative provinces - Olomouc and Brno (and later three as the Znojmo territory was separated from the territory of Brno in 1101). Another change occurred at the end of the 12th century when the Late Hillfort administrative provinces were replaced by the Moravian Margravate (Procházka 2009, 99; Wihoda 2010, 9, 154; Žemlička 1998, 295).

In the newly established administrative system of strongholds, all centres were far from equal. Based on the criteria of 1) power, 2) protection, 3) crafts and raw materials, 4) cult and 5) trade; they 
can be hierarchically subdivided into three groups, where in some of them the classification is not necessarily definite and could have changed over time (Procházka 2009; Wihoda 2010; Kalhous 2018). A prominent place among Moravian centres in the 11th-12th century was held by the princely residences in Olomouc and Brno where the administrative and legal power was concentrated. In the mid-12th century the Brno administrative region perished and the princely power moved to Znojmo. Further, it is possible to single out a second category of centres administering regional districts. These include Rokytná, Bítov, Břeclav, Hodonín, Přerov, Pustiměř - Zelená Hora, Spytihněv, Strachotín - Dolní Věstonice and probably Hradec nad Moravicí as well. Strongholds belonging to the third category fulfilled a defensive function or were entrusted with collecting duty. This group may have incorporated sites such as Drnholec, Hrádek, Kramolín, Kroměříž, Palliardiho Hradisko, Hradisko near Svitávka, Sudoměřice, Vranov, etc. (Procházka 2009; Wihoda 2010).

Compared to the Great Moravian centres from the 9th-10th century our knowledge concerning the appearance of the Moravian hillforts from the 11th-12th century is rather sparse. As a result, investigating them is important and necessary. These sites include Rokytná, which governed its own administrative district and as such held a prominent position among the Přemyslid centres in Moravia. However, our data on the form of occupation in the hillfort is quite limited. The aim of the presented research was therefore to extend it with new data acquired with the help of a combination of non-invasive survey methods. The present contribution summarises our results and attempts to present them in the context of well-known facts.

\section{The site}

The site is situated in the Oslavany basin on a rock spur accessible from the south, with the Rokytná river flowing around the remaining three sides (Fig. 1). The elevation of the rock spur varies between 245 to $260 \mathrm{~m}$ and it rises above the valley of the river which runs at an elevation of $225 \mathrm{~m}$. The rock spur is subdivided into two sections. The Southern Section - Bailey with an area of c. 8.5 ha - featuring an access neck c. $100 \mathrm{~m}$ wide where the municipality of Rokytná is situated today. The undeveloped part of this area is called Malé Hradisko (Little Hillfort). The northern section - Velké Hradisko (Great Hillfort) - is separated from the rest of the rock spur by a second neck about $130 \mathrm{~m}$ wide. The area of the Great Hillfort covers c. 3.5 ha and presently it is agricultural cultivated land apart from a section near the rampart which is protected by a fence and adjoins gardens in the Little Hillfort.

\section{Archaeological excavations and historical sources}

Early finds confirming the archaeological past of the site and, most importantly, its significance in the Late Hillfort period come from the end of the 19th century. I. L. Cervinka calls it as "Rokytengrad" and mentions the finding of burials in sandpit under the village dated according to the denarii of Konrád I. of Brno (Červinka 1928, 133). Furthermore, an accidental find of a settlement feature from 1942 in Little Hillfort was published. It contained fragments of ceramic vessels, one complete and two damaged spindle whorls, and the denarius of Konrád I. of Brno (Nekuda-Sejbal 1960, 23-26). The first archaeological excavation took place there in 1959 and 1960. B. Novotný carried out an excavation of settlement and fortification in which he concentrated mainly on the Great Hillfort area. The work included trenches on the edge of the site as well as trenches throughout the whole area and trenches within the perimeter of the municipality (Novotný 1975; 1981, 223). Further investigation did not take place until the rescue excavations within the bailey (Čižmář 2003; 2004; Parma-Španihel 2015; Procházka 1985). A summary processing of the excavations has not been completed yet.

There is site evidence of settlement activities from the prehistory and the Early Middle Ages (8th-10th century). The site attained the greatest significance in the 11 th-12th century when a hillfort was built there with its own administrative district (Procházka 2009; Novotný 1975; 1981). 


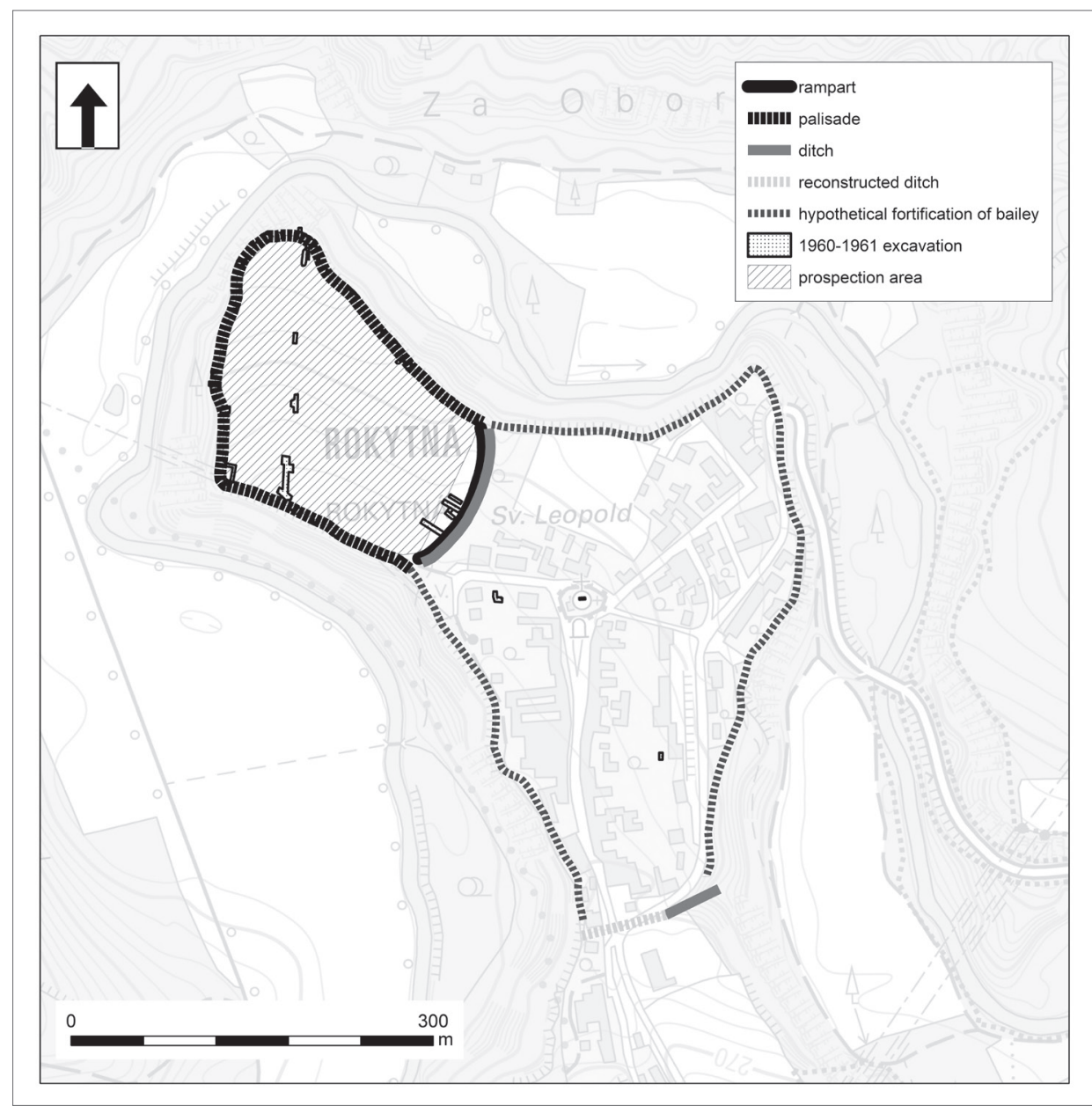

Fig. 1. Localisation of archaeological excavations, fieldwalking and geophysical survey at Rokytná hillfort. Source ČÚZK. Spatial localisation of the archaeological excavated areas is based on the map by Novotný (1981).

Obr. 1. Lokalizace archeologického výzkumu, povrchových sběrů a geofyzikální prospekce na hradisku Rokytná. Zdroj ČÚZK. Lokalizace archeologických sond byla provedena na základě mapy B. Novotného (1981).

The hillfort is mentioned in several documents, although none are original. These are younger counterfeits - copies of older documents that have been more or less modified. It is therefore necessary to approach them with reserve (Šebánek-Dušková 1964, 54). In the founding deed of the Opatov monastery it is granted market tolls in Rokyten. According to V. Hrubý this deed had to have been re-written after 1163 (Hrubý 1936, 131-138). In the founding deed of the Stará Boleslav chapter it was awarded tithes from the administrative district of Rokiten, which was also to pay one talent and two oxen. According to V. Hrubý the deed was forged after 1298 (Hrubý 1936, 73-79). The documents contain credible cores, act records corresponding in content to the second half of the 11th century. In the second half of the 12th century, these pensions would already be an anachronism (Petráček 2012; 2017).

From written sources it is also possible to deduce the date of the destruction of the hillfort. This is related to the campaign of the Bohemian Duke Vladislaus II against Conrad II of Znojmo 
in 1146, which is known from the report of the Bishop of Olomouc Jindřich Zdík (Wihoda 2010, 195). A later destruction date is also possible in connection with the year 1185 and the defeat of Margrave Conrad II. Otto by Duke Frederick in the battle near Loděnice, east of Moravský Krumlov (Měřínský 1980; Novotný 1981, 227). The forceful end to life on the rock spur is documented by traces of a great fire uncovered during excavations. After the end of the power centre only the settlement in the bailey was rebuilt, with the core of today's village created around the church (Novotný 1981, 230).

Information on the appearance of the hillfort is sparse, which corresponds to the limited extent of past excavations. These were focused mainly on the research of residential features and fortification of the acropolis. The hillfort consisted of two parts, the main centre had to have lain on the rock spur in the location now called the Great Hillfort (Fig. 1). It was protected by a palisade around its perimeter and separated from the bailey by a rampart and a ditch. The ditch was c. $140 \mathrm{~m}$ long and the material dug up during its construction was piled up on the inner side to make a rampart with a height of c. 4 to $7 \mathrm{~m}$ from the bottom of the ditch. The crown of the rampart could have been about $6 \mathrm{~m}$ wide. A $75 \mathrm{~cm}$ wide and $65 \mathrm{~cm}$ deep trough to sink the wooden palisade into was identified in its uppermost part (Novotný 1960,99). In the south the bailey was separated from the surrounding elevated plain in the narrowest section by a $100 \mathrm{~m}$ long ditch, and probably by a rampart that has not survived (Novotný 1975, 2; Procházka 2009, 201). The supposed ditch dividing the inner area of the suburbium into two parts (Čižmář 2004, 240) was refuted by later archaeological excavation (Parma-Španihel 2015, 291).

Settlement features included sunken featured dwellings with stone ovens or hearths and pits of various shape. In the north-east section of the Great Hillfort, close to the inner side of the rampart, a large burnt timber structure sized $10 \times 11 \mathrm{~m}$ was uncovered. The sunken huts were identified mainly in the trenches around the hillfort perimeter, although they also occur within the central space. Based on the results of the excavations B. Novotný situated the main settlement in the Great Hillfort at the south-west edge. According to the find context the sunken huts dated to the 11th-12th century adjoined the fortification palisade. A number of settlement features from the 11th to 12th centuries were also discovered in the suburbium. They are overlaid with high medieval and modern settlement (Čižmáŕ 2004, 241; Novotný 1960, 99; 1981, 223, 230; Parma-Španihel 2015, 291).

\section{Methodology}

Earlier excavations in the Rokytná hillfort provided basic data on the occurrence and types of features and their dating, while the structure and density of the occupation remained unknown to us. One of the alternatives for acquiring at least basic knowledge regarding theses issues is a non-invasive survey. Within a short time and with low financial requirements it is capable of providing us with information that can be used in the future for planning dedicated archaeological excavations. In Rokytná there are favourable conditions for this survey on the location of the Great Hillfort, which is simultaneously considered to be the acropolis, or the main part of hillfort. The whole of this section is today used as arable land and is easily accessible. The bailey, with the exception of a small area in the north-west section, the so-called Little Hillfort, has been built over with modern development and carrying out any surveying activities is rather limited.

In determining the best solution to extend our knowledge of the site the most suitable alternative was offered by a combination of archaeological fieldwalking and geophysical survey. Surface collection of artefacts can provide information on the intensity of settlement and its dating in the different sections of the site. A geophysical survey can acquire data on the presence of individual features and the structure of settlement as a whole. At the same time, both methods indirectly indicate the state of preservation or disruption of the site by modern field activities, such as agriculture.

Fieldwalking by means of detailed spatially recorded collections is a suitable tool for specifying the nature of archaeological features identified and located by geophysical survey 
(Drnovský et al. 2020; Janovská-Klír 2020; Křivánek 2012; Music et al. 2000; Trachet et al. 2017). Fieldwalking in Rokytná were carried out in the spring, immediately before the start of agricultural field work, it generally being the most suitable time.

Fieldwalking was carried out in lines divided into $20 \mathrm{~m}$ long sections. The lines were not set out independently but followed the survey route with a magnetometer. They ran down the slope (in parallel with the direction of erosion) and they were c. $20 \mathrm{~m}( \pm 2 \mathrm{~m})$ apart. This type of prospecting serves to acquire data with high spatial precision and has been deployed and verified on several sites (Kuna 1994). The total surveyed area reached c. 3.5 ha, covering the whole arable land of the Great Hillfort and in principle overlaps the area of geophysical prospecting (Fig. 1).

The ceramic material found on the site comes from features and layers disrupted by agricultural activity and soil erosion. This is unfortunately reflected by the condition of the material, which is significantly damaged and fragmented. It applies mainly to the prehistoric and the early medieval component, the life expectancy of which after being ploughed from the original feature or layer is just a few years. This is in contrast with the hard fired high medieval and modern ceramics that are much more resistant to the post-depositional processes. Apart from the destruction of artefacts agricultural activity is also responsible for their dispersion in the surroundings. The process lasts several years, after which the artefact disintegrates (Beneš 1998; Dunnell-Simek 1995; Reynolds 1982). In addition, one needs to consider slope erosion, which occurs even with a gradient as low as $2^{\circ}$ (Blanco-Lal 2008; Kuzucuoglu et al. 1992). By means of an experiment it was observed that at an $11^{\circ}$ slope experimentally placed artefacts were shifted by $10 \mathrm{~m}$ after two storms. In the course of the next four years c. $80 \%$ of artefacts were captured $50 \mathrm{~m}$ further down the slope (Allen 1991). The gradient of the slope in Rokytná in the Great Hillfort is as much as $10^{\circ}$. As a result we have to take into account the travel of artefacts from the sources of their original occurrence to lower-lying sections of the site. A considerable level of erosion in the central part of the fort was confirmed by archaeological excavation early in the 1960s (Novotný 1975).

Within the geophysical methods, a magnetometer survey has the greatest potential for the detection of settlement structures expressed in the form of sunken features. It measures the intensity of the magnetic field of the Earth and detects anomalies of various type and origin, among them those of an archaeological nature (Aspinal et al. 2008; David et al. 2008; Fassbinder 2017; Gaffney 2008; Neubauer 2001; Schmidt et al. 2016). On early medieval sites we can expect positive results in locating features magnetised by the effect of the magnetic field under conditions of considerable changes in temperature (Le Borgne 1960). These comprise, for example, of burnt layers, ovens and fireplaces, as well as hoards of individual iron objects. Sunken features with a secondary fill of darker earth with organic remains and magnetic minerals are easily detectable as well (Fassbinder 2015; Fassbinder-Stanjek 1993). Here we can include sunken huts, ditches and different settlement pits.

Given the nature of the archaeological features in the Rokytná hillfort, by archaeological reports comprised of sunken huts and various settlement pits, it was decided to carry out a magnetometer survey. Positive results could also be expected given that archaeological investigation confirmed traces of fire at multiple spots. Other methods, such as geoelectric resistivity measurement or GPR survey would come in turn in the case that data from magnetometer survey would show traces of stone architecture. As such features were not identified further geophysical activities were tentatively abandoned.

The total area surveyed on the hillfort of Rokytná reached 3.54 ha. The survey covered the entire available area of the acropolis (Fig. 1). The prospection was carried out with a fluxgate magnetometer LEA MAX (Eastern Atlas, Germany). The instrument is designed as a gradiometer with 10 fluxgate probes (FEREX CON 650, Foerster, Germany). The density of the magnetometer measurements was $0.5 \mathrm{~m}$ on the $\mathrm{X}$ axis and $0.1 \mathrm{~m}$ on the $\mathrm{Y}$ axis (measurement direction). Measurement data was processed using the standard procedure in the LEAD2 programme. The magnetic field intensity map (magnetogram) in nanoTesla (nT) units was then smoothed by averaging. 
After the evaluation of data from surface collections and the geophysical survey we proceeded by comparing the results of both methods. ArcGIS Desktop10.7 (ESRI) software was used to present and interpret the results. Settlement density was analysed, using the spatial analysis of kernel density (ESRI, 2020). The aim was to observe the extent to which the data on settlement intensity acquired from surface collecting is similar to the results from the magnetometer survey.

\section{Results}

Surface collections yielded in total 6,429 artifacts, of which 6,283, i.e. $97.8 \%$ of finds, consisted of ceramic shards. Also found were 63 items of daub, 8 items of stone artefacts, 67 items of iron slag, 3 whorls, 2 semi-finished/game pieces, a fragment of a polished stone axe, a nail and a small hoof.

The most important source for learning about the settlement on the site was pottery. These were chronologically divided into three basic categories (Malík-Peška 1994; Procházka-Peška 2007; Šebela-Vaněk 1985):

1) The most recent component consisted of thin-walled high medieval and modern ceramics dateable to the 13th-20th century. It is typified by fine and hard fired clay. Thanks to quality firing we can expect longer survival in the layer of arable land compared to the prehistoric and early medieval ceramics. This category possibly includes $36 \%$ of the shards. The average weight was 2.95 grams.

2) The second component is graphite ceramics, which chronologically belongs to the 2 nd half of the 11th-12th century, i.e. to the period of the hillfort's existence (Fig. 2:2). These ceramics are prone to damage by agricultural work. As such we can expect less dispersion of ceramic fragments from the original sources as the shard breaks into pieces soon after being unearthed by ploughing. This category possibly contains $19 \%$ of the shards. The average weight was 9.96 grams.

3) The last component is a mixture of prehistoric and early medieval shards, the vast majority of which are impossible to date more precisely (Fig. 2:3-11). They belong to the whole period when the site was used from the Neolithic to the 12th century. Most of this component probably falls within the period of the existence of the hillfort, but it cannot be clearly distinguished from earlier material. To a lesser extent this set comprises finds from the 9 th-10th century and prehistoric fragments. This category possibly contains $45 \%$ of the shards. The average weight is 6.53 grams.

The evaluation of high medieval and modern ceramics (component No. 1) shows the highest concentration of shards in the vicinity of the rampart (close to the present village) and in the northeast section of the acropolis (in the area below the slope; Fig. 3:A.). In general, they are highly fragmentary pieces originating from standard village waste dumped in the field. This component cannot in any way be associated with settlement on the site, nor is it possible to observe any link to the division of the fields. The distribution of this component corresponds to the distance from a later settlement, the gradient of the terrain and erosion processes.

To understand early medieval settlement of the site it is necessary to evaluate the graphite ceramic (component No. 2). Material from this period is dispersed throughout the whole area of survey (Fig. 3:B). We can observe three larger concentrations: the first with an area of c. $40 \times 60 \mathrm{~m}$ near the south-west edge; the second sized c. $60 \times 80 \mathrm{~m}$ along the rampart in the neck, mainly towards the north-east end; and the third sized c. $100 \times 50$ m near the north-east edge of the rampart. Two additional smaller accumulations of shards were identified at the western edge and in the northern tip of the rock spur. 
1
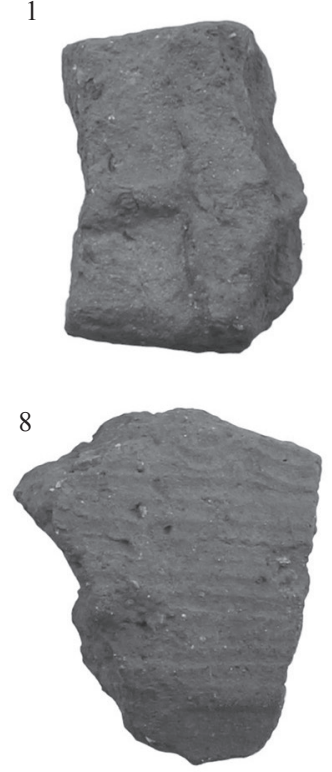

2

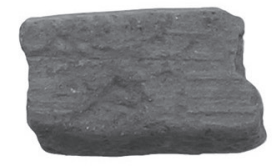

5

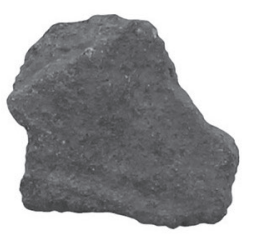

9
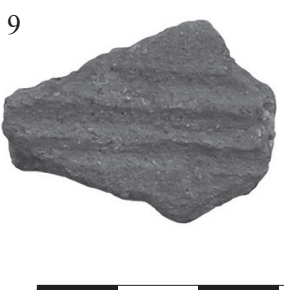

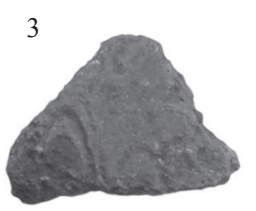

6

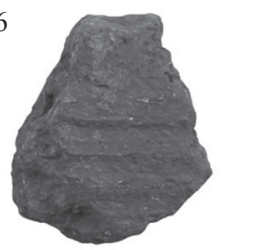

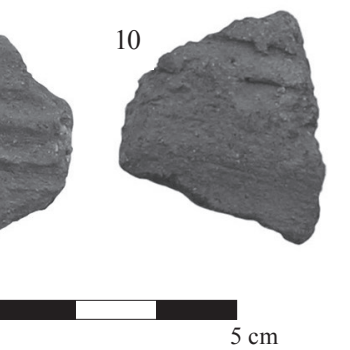

4

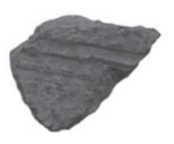

7

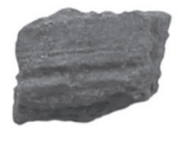

11

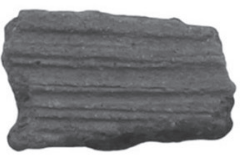

0

$5 \mathrm{~cm}$

Fig. 2. Rokytná. Selection of decorated pottery fragments from the fieldwalking. 1 - pottery mark; 2 - graphite ceramic (2nd component); 3-11 - mixed ceramic (3rd component).

Obr. 2. Rokytná. Výběr zdobené keramiky z povrchové prospekce. 1 - hrnčířská značka; 2 - grafitová keramika (složka č. 2); 3-11 - smíšená keramika (složka č. 3).

The concentration of the third component containing indistinguishable material from the 11 th -12 th century as well as early medieval and prehistoric material generally mirrors the graphite section of the set. It is represented more strongly in the area of the south-west and north-east edge of the rock spur while the concentration is slightly lower near the rampart (Fig. 3:C.).

The geophysical survey confirmed more than 400 anomalies, which can be interpreted as potential archaeological features. In the majority their precise classification is questionable. They are predominantly settlement pits of different shape and function. In 10 to 15 cases, it is possible to think of sunken huts with a regular square plan. 8 anomalies can be interpreted as kilns or features with significant traces of fire (20 to $100 \mathrm{nT})$. Alongside the northern edge of the rock spur, we can observe c. $20 \mathrm{~m}$ wide band free of any features. Another area without any larger sunken features is a c. $50 \times 50 \mathrm{~m}$ square in the central part of the surveyed surface (Fig. 4).

As a whole, the built-up areas in the hillfort exhibit certain regularity (Fig. 5). The features are dispersed throughout the survey area quite regularly. A larger concentration of features within an area of c. $60 \times 30 \mathrm{~m}$ is found in the north-east section of the acropolis. There has been no expression observed of roads or regular entities which might be termed farms/farmsteads. Magnetic anomalies interpreted as kilns form a cluster at the western edge of the site.

In the north-west and north-east part, alongside the hillfort perimeter, 8 sections with a total length of $160 \mathrm{~m}$, exhibiting higher magnetic values (5 to $10 \mathrm{nT}$ ), were registered. With certainty, they are not recent disruptive structures, but burnt segments of the fortification. In this way the magnetometer survey confirmed the destruction of the fortification whereby we may assume that the fortification burnt down in its complete length (Fig. 4, 5). 

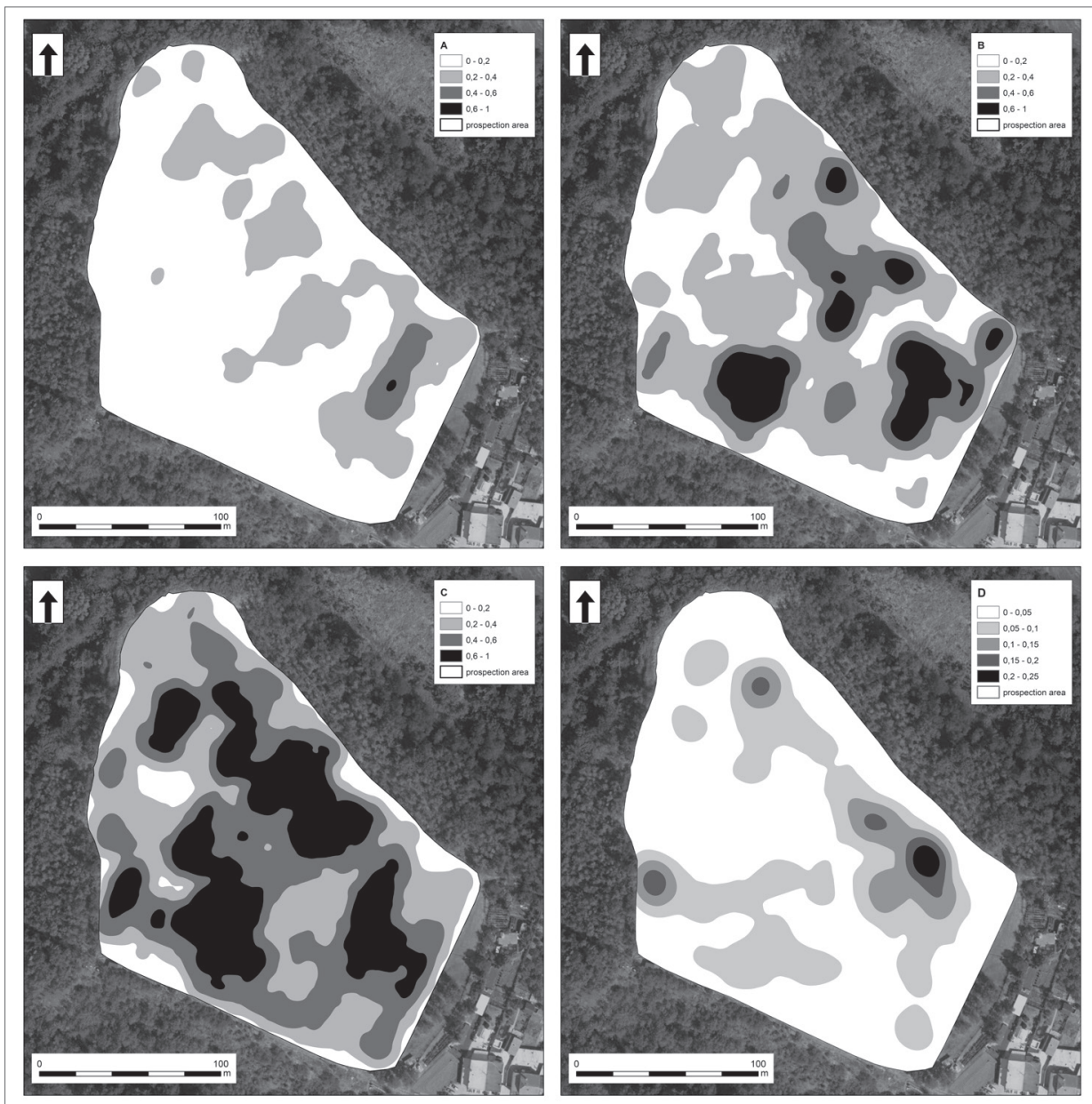

Fig. 3. Rokytná. A - distribution of high medieval to modern pottery (component No. 1); B - distribution of graphite pottery from the 11th-12th century (component No. 2); C - distribution of material containing difficult to determine ceramics from the 11th-12th century as well as early medieval and prehistoric material; D - settlement density expressed by the area of magnetic anomalies interpreted as settlement features.

Obr. 3. A - distribuce sběrového materiálu vrcholně středověké a novověké keramiky (složka č. 1); B - distribuce grafitové keramiky z 11.-12. století (složka č. 2); C - distribuce sběrového materiálu, který obsahuje těžce odlišitelnou keramiku z 11.-12. století, jakož i starší raně středověký a pravěký materiál; D - hustota osídlení vyjádřená plochou, kterou zaujímají magnetické anomálie interpretované jako sídlištní objekty.

Numerous recorded features have no link to prehistoric and medieval settlement. They include linear structures, the origin of which can be sought in pedological and geological phenomena (Fig. 5). A band c. $7 \mathrm{~m}$ wide running from north to south-east throughout the acropolis is of erosive origin. It exhibits higher magnetic values than the other parts of the site and is formed by surface washes from the higher elevations of the terrain. A layer of material up to $120 \mathrm{~cm}$ thick washed from the higher elevated spots was identified near the northeast edge of the hillfort by B. Novotný (1975). Another group is made up of sources of disturbance. These include small iron objects distributed throughout the area of the hillfort. They were brought there mainly during modern agricultural activities. Strong interference is also generated by fences and structures situated immediately eastwards and southwards of the survey area. 


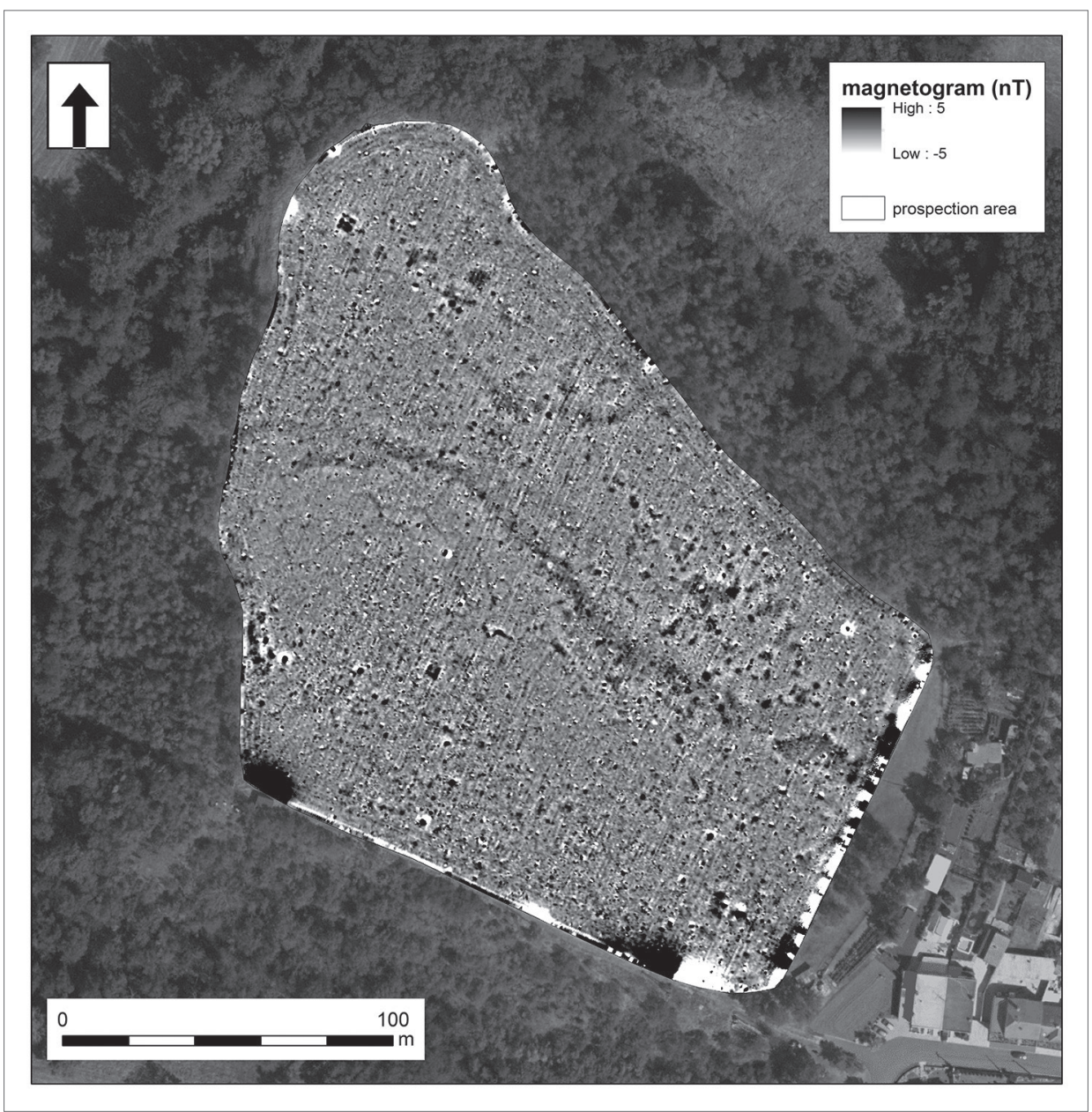

Fig. 4. Rokytná. Magnetic map of the surveyed area.

Obr. 4. Rokytná. Magnetogram prozkoumané plochy.

A comparison of the results of surface collecting with the result of a geophysical survey highlighted one fundamental trend: The concentrations of the graphite and the mixed ceramic component mirror the occurrence of features confirmed by geophysical survey (Fig. 3:B, C, Fig. 6). An exception is a group at the northeast edge of the rock spur which penetrates the area between the two concentrations of detected features. At the same time, it was shown that the concentrations of shards do not automatically signify an increased number of archaeological features in the form of magnetic anomalies. Consequently, the clusters of ceramics on the site are mostly related to the intensity of disrupting the sunken features and post-deposition processes. There is less ceramic material in the central part of the rock spur. This correlates with the empty space identified by a geophysical survey. The phenomenon can be probably explained by a combination of erosion and less dense settlement.

In addition to shard material, we observed the distribution in space of daub and iron slag. Monitoring the occurrence of daub did not bring any substantial information. The finds of daub are sporadic and generally correspond to the five concentrations described in the graphite component. 


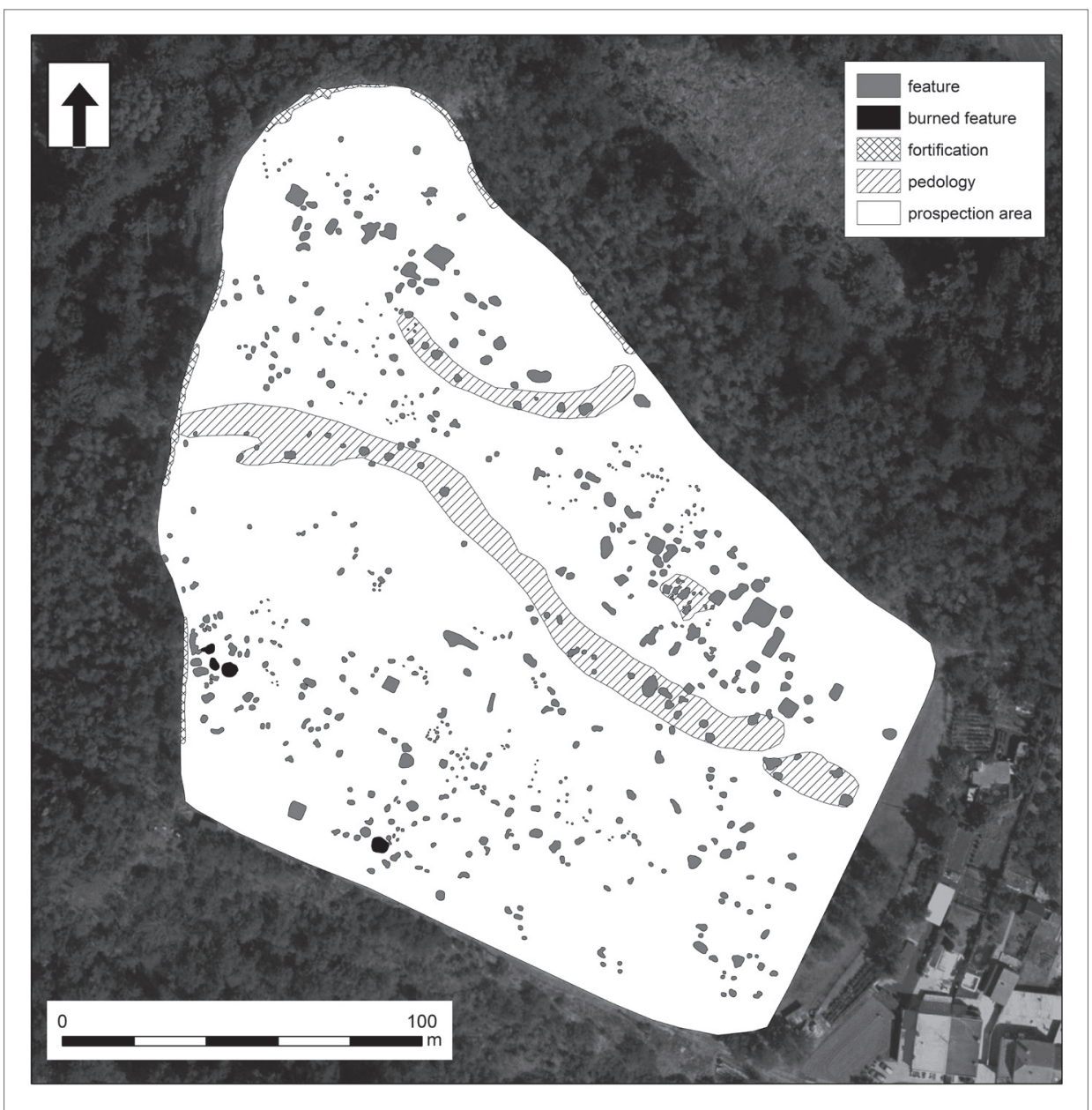

Fig. 5. Rokytná. Archaeological interpretation of the magnetometer survey data.

Obr. 5. Rokytná. Archeologická interpretace geofyzikálního průzkumu.

On the other hand, the finds of iron slag are interesting. It sporadically occurs throughout the hillfort, but the main concentration relates to the area of the south part of the western edge of the hillfort. The geophysical survey found several features there which could be interpreted as kilns. Consequently, this part of the hillfort could tentatively be termed a potential metallurgical/iron metallurgical district. Finds of slag support this assumption but without archaeological excavation of the identified anomalies it cannot be clearly confirmed.

\section{Discussion}

A geophysical survey registered dense settlement within the hillfort area. However, the real number of archaeological features on the site is with certainty higher than the number of features identified. We may have not recorded features surviving only in fragments or those which do not provide sufficient magnetic contrast against their surroundings. An important factor was strong erosion that must be considered on the site. The whole investigated surface slopes from 


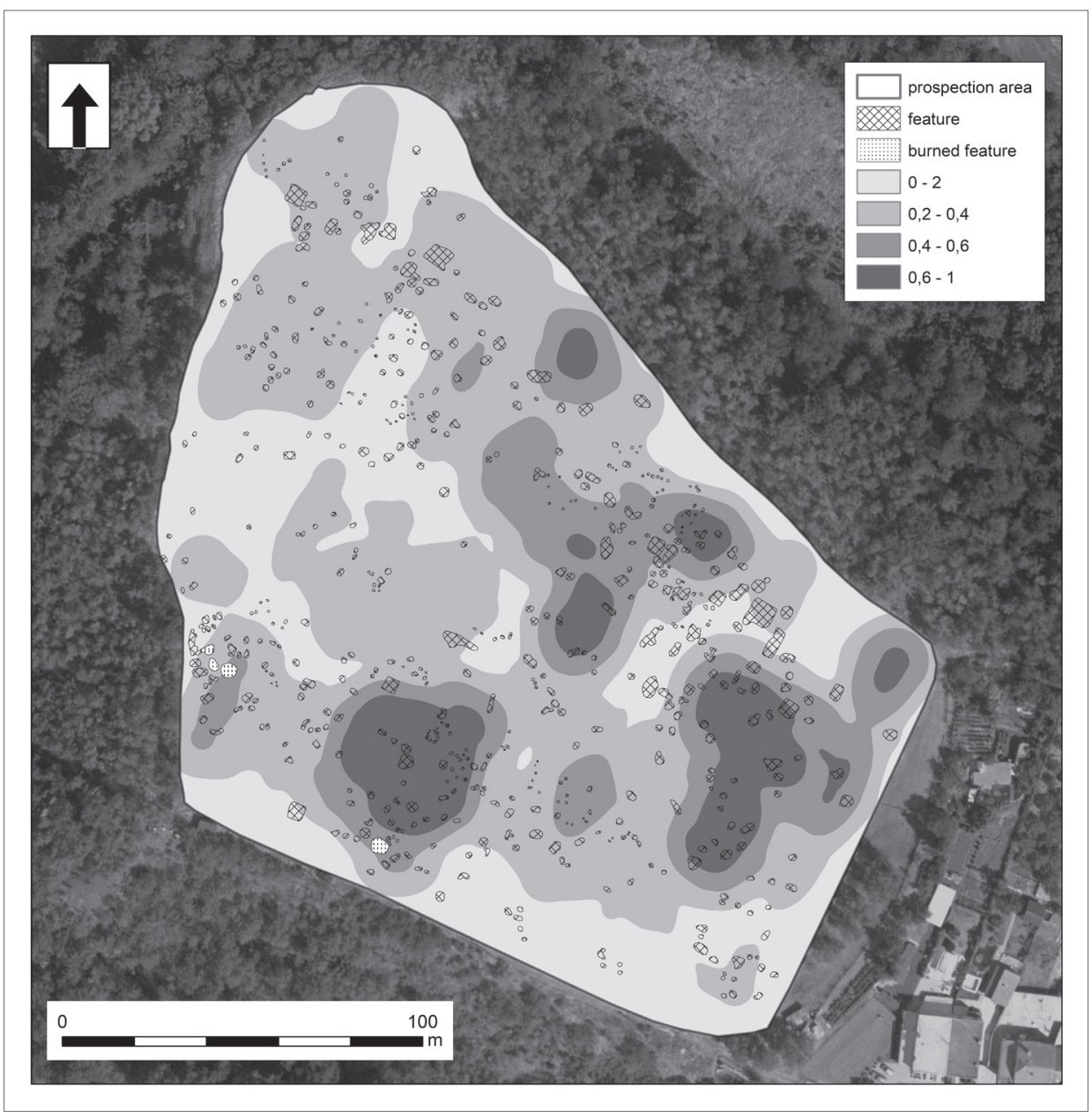

Fig. 6. Rokytná. Overlay and visual comparison of geophysical anomalies and artefacts dated to the period of the existence of the hillfort in the 11th-12th century (component No. 2).

Obr. 6. Rokytná. Porovnání anomálií zjišsěných pomocí geofyzikálního průzkumu s keramikou datovanou do období existence hradiska v 11.-12. století (složka č. 2).

its southern edge towards the north at an angle of up to $10^{\circ}$, which is conducive to strong erosion (Blanco-Lal 2008). In the magnetic map we can observe it in the form of sediments at the lower elevations of the slope. Strongly eroded settlement features were mentioned even earlier by B. Novotný (1975). His test digs make it obvious that numerous features from the time of the existence of the hillfort were quite shallow (cca. to $50 \mathrm{~cm}$ ). In many cases they were partly sunken huts. Their bottoms had additional dugout pits with heating arrangements. Features in the sloping part of the hillfort were obviously strongly affected by erosion which shifted their material to the lower-lying part, or even outside the hillfort. Numerous shards transported by erosion were recorded by B. Novotný (1975) at the northeast edge of the hillfort. Another blow that the hillfort suffered was dealt by agricultural activity. Deep ploughing damaged or destroyed the shallow features. Most features in the magnetic map can therefore be interpreted as settlement pits as well as pits originally dug out in the floors of grub houses while the plans of the houses themselves have not survived. 
These findings are not exceptional in the context of early medieval hillforts. Similar observations in geophysical surveys have been reported elsewhere. The results of the magnetometer survey of the Přemyslid stronghold in Prague-Královice showed thoroughly ploughed surfaces with only fragmentary preservations of sunken situations in the subsoil layer (Křivánek 2019, 148, Fig. 4). Identical reports relate to other sites, such as Kouřim - Sv. Jiř́, where it is possible to observe a whole range of disrupting impacts, such as landscaping and agricultural ploughing (Křivánek 2013, 281-283, Fig. 5). The difference in the preservation of settlement features in the Rokytná hillfort at the time of excavations by B. Novotný compared to today may be enormous. During 60 years of intensive agricultural activities and soil erosion we have lost numerous features or their parts, and with them valuable information. The rapidity and intensity of these changes can be confirmed in other early medieval forts excavated in the past, such as the site in Vlastislav. Compared to the period of excavations in 1953-1960, most of the settlement has been ploughed up today (Křivánek 2019, 151, Fig. 7).

Given the confirmed fragmentary preservation of archaeological features in the hillfort, resolving the issues concerning the settlement structure is problematic. During excavations dwellings in the form of huts were observed in multiple trenches - alongside the south edge, in the southwest corner and at the western edge of the rock spur, as well as in the inner area of the hillfort (Novotný 1975). In the magnetic map, sunken featured dwellings appear only rarely, as they do elsewhere. If we accept the assumption that only pits dug out in their bottoms have survived, the density of geophysically detected features corresponds to the situation reported during the excavations. In this case, the whole area of the acropolis can be considered as having dense and regular settlement. Archaeological fieldwalking pointed out potential concentration of settlement, but in comparison with geophysical data we can state that the accumulations of ceramic material are mostly an expression of the post-depositional processes on the site (Fig. 6).

Dense settlement detected during geophysical survey of the whole area of the hillfort is known from other similar sites as well. They include, for example, Libice nad Cidlinou (Křivánek-Mařík 2009), Zámka in Prague-Bohnice (Křivánek 2008), Prague-Kralovice (Křivánek 2019, 148, Fig. 4) and others. The density of habitation is an indicator of the importance of these sites, compared with fortified precincts with a prevalent defence function. However, as in Rokytná, in these forts it is impossible to assign the recorded anomalies to any particular type of feature or to specify the structure of the built-up areas in greater detail. Only in Libice nad Cidlinou did the authors of the survey reconstruct the road network, which is related to the location of the gates (Mařík-Křivánek 2012, Fig. 4). In Rokytná, such analyzes could not be carried out due to the fact that we do not know the entrance into the acropolis.

Regardless of the limited possibilities of interpretation of the results of geophysical measurements, in Rokytná we can single out areas with potential specific functions. One of these is an area at the western edge of the hillfort (Fig. 4, 5). Anomalies with high magnetic values (20-100 nT), which can be interpreted as kilns, indicate the existence of a production district. Numerous pieces of iron slag found during fieldwalking as well as past excavations (Novotný 1975,10 ), point to the possible processing of iron. Another option is a fire that broke out in this part of the area. Better understanding of this find context requires that a dedicated excavation be carried out.

Another specific area sized c. $1,800 \mathrm{~m}^{2}$ is situated in the north-east part of the investigated surface (Fig. 4, 5). It exhibits the highest settlement density in the acropolis. We can assume this to be the kernel of settlement with multiple re-developments or phases. But we cannot rule out the alternative that medieval settlement overlays earlier settlement activities which failed to have left significant shard material behind them. In this case the given issue can again be explained by excavation.

Issues related to the expected presence of religious architecture and profane buildings of a higher order or the location of the marketplace remain unresolved. The incomes granted to church institutions suggest an important re-distribution role of the hillfort, which belonged to the 
main administration centres in the land, immediately after Olomouc and Brno - the centres of the large administration provinces. Undoubtedly, there was an important marketplace situated there, as in the other centres of this category (Fleková et al. 2012). However, neither geophysical data nor archaeological fieldwalking point to the possible location of this market. It is possible though that the markets took place in the relatively greater bailey. Settlement structure in the bailey is known to us only in fragments. Excavations confirmed dense settlement particularly in the northern section, adjacent to the ditch of the acropolis. The question to be resolved is the nature and density of the early medieval occupation in the remaining section towards the expected outer fortifications of the bailey (Fleková et al. 2012, 280).

The geophysical survey in the acropolis has not revealed any significant architecture. Construction material in all detected features probably consisted exclusively of a combination of wood and clay. Given the importance of the site it can be assumed that a religious building built in stone stood there, although maybe not in the acropolis of the hillfort. It is more likely that such a building was situated nearby or on the location of the medieval church in the centre of the village in the bailey. Based on existing data it seems that the detectable medieval substance of the standing church did not originate until after the destruction of the hillfort in the late 12th or the beginning of the 13th century. The presence of a potential earlier building there has so far been suggested only by problematic finds. These include, for example, paving tiles, found in a context with ceramics from the late 11th to the 12th century, but the tiles themselves could date from the late 12th and the 1st half of the 13th century (Fleková et al. 2012).

The position of the bailey in relation to the acropolis need not have been inferior at the time of the hillfort working as an administrative centre. It is indicated by the ditch which divided the bailey into two parts. Its role was undoubtedly to separate a part of the bailey with a different function from its surroundings. In terms of defence the primary position was held by the acropolis which in case of an emergency was the best protected and most easily defensible. We have evidence there of dense settlement including production or processing activities. But administrative, trading and religious activities could have primarily taken place in the space today described as the bailey. Given the lack of information on the structure of the built-up areas in the bailey we have to leave the issue of its function open for the time being. A large-scale geophysical survey is no longer possible there and new data could be provided mainly by additional archaeological excavation.

When we look at the Rokytná hillfort in the context of other forts from the 11th-12th century within the territory of the Přemyslid domain in Moravia, we find many similarities as well as differences. Our knowledge of the appearance of the hillforts from that period is rather limited. In the Moravian territory archaeological research has concentrated in the long term rather on resolving issues of the power centres related to the existence of the Moravian principality in the 9th-10th century. Sites from the 11th-12th century of comparable significance to Rokytná were investigated only marginally. They include Bítov (destroyed by a later high medieval castle), Břeclav (the total extent of settlement is unknown), Hodonín (destroyed by later development, today situated in the location of the chateau and the historical core of the town), Přerov (also in the location of the historical core of the town), Pustiměr - Zelená Hora (only simple trenches carried out there), Strachotín - Dolní Věstonice (only small-scale excavations, mainly the rampart) and probably Hradec nad Moravicí (extent of settlement unknown) and Spytihněv (Procházka 2009). As an analogy it is best to use Spytihněv and Přerov. Spytihněv was an important centre and one of the largest among the sites mentioned above, like Rokytná. Unfortunately, the greatest part of the site was destroyed by the meandering Morava river. Similarity with Rokytná can be seen in the frequent occurrence of Late Hillfort ceramics and the presence of sunken settlement features (Novotný 1978). Several settlement features from the 10th - 1st half of the 11th century were discovered in Prrerov. In that time this place served as a Polish base in Moravia during the reign of Boleslav the Brave (Procházka 2018, 170). The fortification consisted of a wooden-clay rampart with a grate construction. The settlement structure consisted of a number of dwellings, which were located on the main castle in two to three lines 
parallel to the fortification (Procházka 2007, 40; 2017, 117-123). A similar situation was found by B. Novotný at the northwestern edge of the acropolis in Rokytná (Novotný 1975, 10). From the 11th to the 12th century we know from Přerov pyrotechnic devices, burial grounds and possible market-related evidences in the form of a ceramic egg from Kievan Rus with weight of 6 Břetislav's denarii (Procházka 2018, 163, 164, 168).

Centres of the first order (Olomouc, Brno and Znojmo) do not provide much information either as they were destroyed by later transformation into high medieval centres. The exact extent and density of population is difficult to determine today. Due to the limitations described above, these centers can serve to compare the character of individual objects, rather than as an analogy about the overall structure of the settlement. Thanks to rescue excavations, we can get a rough idea of their appearance. A wood-clay fortification with a ditch is documented in Brno (Zapletalová 2017, 22). Extensive excavation of the Přemyslid lowland center was carried out in Staré Brno/Old Brno - Vídeňská Street. Numerous pits of various character were discovered. Dwellings were probably built mostly on the ground level (Holub et al. 2010, 426, 427). The fortification of the Olomouc Acropolis consists of two outer dry stone walls and a lighter fortification of the suburbium (Šlézar 2018, 123-125). The settlement had a wood-clay character, numerous sunken featured buildings were found (Bláha 1984, 136; Čižmář-Lečbych 2010, 489; Procházka-Wihoda-Zapletalová 2011, 520). Furthermore, weekly markets, which were connected to long-distance trade, are documented from written sources and archaeological finds (Bláha 1991, 43; 2000, 187, 190; Šlézar 2018, 128; Zapletalová 2017, 33). In the case of Znojmo, it is perhaps possible to directly consider the specific location of the market in the undeveloped part (Čižmáŕ-Lečbych 2010, 489). Furthermore, in Brno, Olomouc and Znojmo were found the remains of various pyrotechnic objects, whether ovens for cooking (Procházka-Wihoda-Zapletalová 2011, 520 ), or evidences of metal processing in the form of iron slag, metallurgical furnaces or graphite crucibles for processing copper or silver alloys (Bláha 1984, 136; Procházka-Wihoda-Zapletalová 2011, 521-522; Procházka-Hložek-Závodná 2011, 71-75; Šlézar 2018, 128).

A burial grounds were found in Brno, Olomouc and Znojmo (Bláha 1984, 137; ProcházkaWihoda-Zapletalová 2011, 522). In Brno were found three churches from the period - Rotunda of the St. Virgin Mary on Mendel Square, the second rotunda on the right bank of the river Svitava (both in Staré Brno/Old Brno) and also the Church of St. Peter (Procházka-Wihoda-Zapletalová 2011, 511; Zapletalová 2017, 34-36). Sacral architecture was also abundant in Olomouc, where was, in addition to churches, also a bishop's palace (Bláha 2001, 137; Šlézar 2018, 124). One rotunda was also founded in Znojmo (Wihoda 2010, 202; Zapletalová 2017, 39).

The above-mentioned situations can also be stated in the case of the Rokytná hillfort, but with the exception of sacral architecture, as the dating of the Rokytná Church into Late Hillfort period has not yet been reliably proven (Fleková-Čižmář-Procházka 2012, 296).

\section{Conclusion}

Our knowledge of settlement in the Rokytná hillfort has so far been based on data gained through archaeological excavation. Field survey and geophysical research significantly expands our knowledge. The geophysical survey registered over 400 anomalies scattered throughout the entire area of the hillfort. Most features are of an amorphous shape and only a small part of them can be determined as sunken huts, or kilns. Through a field survey we were able to distinguish three ceramic components. The component relevant to the research into the early medieval hillfort is graphite ceramics dated to the 11th-12th century when a regional centre known from written sources under the name of Rokyten was built there. It can be stated that the concentration of ceramics dated to this period generally corresponds to the concentration of features detected by geophysical survey. We can therefore assume that a great part of the archaeological features registered during geophysical survey belongs to the period of existence of the hillfort. The 
geophysical survey and the archaeological excavation in the 1960s show that occupancy in the whole acropolis was dense with the main concentrations in the more even parts of the surface. However, in most cases it was probably only pits in the floors that survived from the original sunken huts due to erosion and deep ploughing. All the detected features are not contemporary. To identify the different development phases of settlement it will be necessary to carry out further archaeological excavations. Clarification of the character and chronological classification of at least some geophysically identified features will help us to better understand the function of the individual parts of the site, as well as to observe the overall development of the settlement.

This publication is based on research supported by the Czech Science Foundation (GACR) under Grant No. 18-16153S "Early medieval strongholds in the light of non-destructive investigation".

\section{References}

ALLEN, M. J., 1991: Analysing the landscape: a geographical approach to archaeological problems. In: Interpreting artefact scatters. Contributions to ploughzone archaeology (Schofield, A. J., ed.), 39-59. Oxford.

ASPINALL, A.-GAFFNEY, C.-SCHMIDT, A., 2008: Magnetometry for archaeologists. Lanham, Maryland. BENEŠ, J., 1998: Keramika, ornice a reliéf. Výzkum polykulturního osídlení v Kozlech, o. Louny (SZ Čechy), AR L, 170-191.

BLÁHA, J., 1984: Časně slovanská osada v Olomouci a počátky řemeslnicko-kupeckého podhradí - Frühmittelalterliche Siedlung in Olomouc (Olmütz) und Anfänge der Handwerksproduktion und des Handels in der Vorburg, AH 9, 133-146.

- 1991: Nálezy denárových ražeb v Pekařské ulici a otázka charakteru slovanského trhu v Olomouci 10.-11. století. Výroční zpráva 1991 Památkového ústavu v Olomouci. Olomouc.

- 2000: Topografie a otázka kontinuity raně středověkého ústředí v Olomouci. In: Přemyslovský stát kolem roku 1000, 179-196. Praha.

- 2001: Slovanská a středověká Olomouc v archeologických pramenech. In: Archeologické zrcadlení. Olomouc.

BLANCO, H.-LAL, R., 2008: Principles of soil conservation and management. Dordrecht.

ČERVINKA, I. L., 1928: Slované na Moravě a říše Velkomoravská. Brno.

ČIŽMÁ̌̆, Z., 2003: Rokytná (okr. Znojmo), PV 44, 274-275.

- 2004: Rokytná (okr. Znojmo), PV 45, 240-241.

ČIŽMÁŘ Z.-LEČBYCH, M., 2010: Znojmo (okr. Znojmo), PV 51, 488-491.

DAVID, A.-LINFORD, N.-LINFORD, P., 2008: Geophysical survey in archaeological field evaluation (2nd ed.). Swindon.

DRNOVSKÝ, P.-MILO, P.-TENCER, T., 2020: Zaniklá středověká vesnice Habřinka u Hořiněvsi (okres Hradec Králové). Analýza a interpretace povrchových sběrů a geofyzikálního měření - The deserted medieval village of Habřinka, near Hořiněves (Hradec Králové district): analysis and interpretation of surface collecting and geophysical measurements, AH 45, 123-139. https://doi.org/10.5817/AH2020-1-5

DUNNELL, R. C.-SIMEK, J. F., 1995: Artifact Size and Plowzone Processes, Journal of Field Archaeology 22, 305-319.

ESRI 2020: Kernel Density (Spatial Analyst). Dostupné z: https://pro.arcgis.com/en/pro-app/tool-reference/ spatial-analyst/kernel-density.htm, cit. 15. 11. 2020.

FASSBINDER, J. W. E., 2015: Seeing beneath the farmland, steppe and desert soil: magnetic prospecting and soil magnetism, Journal of Archaeological Science 56, 85-95. https://doi.org/10.1016/j.jas.2015.02.023

- 2017: Magnetometry for Archaeology. In: Encyclopedia of Geoarchaeology, Encyclopedia of Earth Sciences Series (Gilbert, A.S., ed.), 499-514. Dordrecht. https://doi:10.1007/978-1-4020-4409-0

FASSBINDER, J. W. E.-STANJEK, H., 1993: Occurrence of bacterial magnetite in soils from archaeological sites, Archaeologia Polona 31, 117-128. 
FLEKOVÁ, K.-ČIŽMÁŘ, Z.-PROCHÁZKA, R., 2012: Nález románských dlaždic z Rokytné. In: Mezi raným a vrcholným středověkem. Pavlu Kouřilovi k šedesátým narozeninám přátelé, kolegové a žáci (Doležel, J.-Wihoda, M., edd.), 279-300. Brno.

GAFFNEY, CH. F., 2008: Detecting Trends in the Prediction of the Buried Past: A Review of Geophysical Techniques in Archaeology, Archaeometry 50, no. 2, 313-336. https://doi:10.1111/j.1475-4754.2008.00388.x

HOLUB, P. et al., 2010: Holub, P.-Kolař́́k, V.-Merta, D.-Peška, M.-Sedláčková, L.-Zapletalová, D.-Zůbek, A., Brno (okr. Brno-město), PV 51, 395-432.

HRUBÝ, V., 1936: Tři studie k české diplomatice, Spisy filosofické fakulty MU v Brně 42, 1-185. Dostupné z: http://hdl.handle.net/11222.digilib/118850.

JANOVSKÁ, V.-KLÍR, T., 2020: Nedestruktivní výzkum zaniklé Havraně (okres Nymburk). Příspěvek k podobě raně středověkých center nižšího řádu - Non-destructive research into the deserted Havran̆ locality (Nymburk district): a contribution to the form of early medieval centres of the lower rank, AH 45, 67-91.

KALHOUS, D., 2018: Building and Organising Central Places and Fortifications as a Manifestation of Princely Power in Early Medieval Europe. In: Moravian and Silesian Strongholds of the Tenth and Eleventh Centuries in the Context of Central Europe. Spisy Archeologického ústavu AV ČR 57 (Kouřil, P.-Procházka, R., edd.), 17-23. Brno.

KŘIVÁNEK, R., 2008: Nové výsledky geofyzikálních průzkumů v širším areálu pravěkého a raně středověkého hradiště Zámka v Praze-Bohnicích, Archaeologica Pragensia 19, 233-256.

-2012: A Comparison of a Surface Artefact Collection and Geophysical Prospection Information - Examples from the Vraný Micro-region, Distr. Kladno, IANSA 3, no. 1, 155-161.

- 2013: Changes of structure and extent of early medieval strongholds in Central Bohemia from geophysical surveys of sites. In: Archaeological prospection. Proceedings of the 10th International Conference - Vienna, May 29th - June 2nd 2013 (Neubauer, W.-Trinks, I.-Salisbury, R.-Einwögerer, B., edd.), 281-284. Wien. https://doi.org/10.2307/j.ctvjsf630.108

- 2019: Přehled geofyzikálních průzkumů raně středověkých hradišt' v Čechách: přínos, omezení, perspektivy. In: Współczesne metody badań wczesnośredniowiecznych grodów Europy Środkowo-Wschodniej (Chrzan, K.-Moździoch, S.-Rodak, S., edd.), 145-154. Wrocław.

KŘIVÁNEK, R.-MAŘÍK, J., 2009: Early Medieval stronghold Libice nad Cidlinou. An example of use of geophysical methods in systematic non-destructive archaeological project, ArcheoSciences, revue d'archéométrie, suppl. 33 (Mémorie du sol, espace des hommes), 93-95.

KUNA, M., 1994: Archeologický výzkum povrchovými sběry. Zprávy ČAS - Supplément 23, Praha.

KUZUCUOGLU, C.-LESPEZ, L.-PASTRE, J.-F., 1992: Holocene colluvial deposits on the slopes of the Paris Basin. In: Past and Present Soil Erosion. Oxbow Monograph 22 (Bell, M.-Boardman, J., edd.), 115-123. Oxford.

LE BORGNE, E., 1960: Influence du feu sur les propriétés magnétiques du sol et sur celles du schiste et du granite, Annales de Géophysique 16, 159-195.

MALÍK, P.-PEŠKA, M., 1994: Soubor časně novověké keramiky z Moravského Krumlova, SPFFBU E 39 , 93-111.

MAŘÍK, J.-KŘIVÁNEK, R., 2012: Nedestruktivní výzkum akropole libického hradiště, SbNM A LXVI, 67-70, 89-90.

MĚŘÍNSKÝ, Z.,1980: Středověké zbraně z okolí Loděnic, okres Znojmo, AR XXXII, 36-47.

MUSIC, B.-SLAPSAK, B.-PERKO, V., 2000: On-site distributions and geophysics: The site of Rodik-Ajdovscina. In: Extracting Meaning from Ploughsoil Assemblages (Francovich, R.-Patterson, H.-Barker, G., edd.), 132-146. Oxford.

NEKUDA, V.-SEJBAL, J., 1960: Keramika ze sídliště 11. století z Rokytné u Mor. Krumlova datovaná mincí, Moravské numismatické zprávy 7, 23-26.

NEUBAUER, W., 2001: Magnetische Prospektion in der Archäologie. Mitteilungen der Prähistorischen Kommission 44. Wien.

NOVOTNÝ, B., 1960: Zjištovací výzkum hradiska Rokytné u Moravského Krumlova, PV 1959, $133-138$.

- 1975: Rokytná (okr. Znojmo), Nálezová zpráva č. j. 1296/75, AÚ AV ČR Brno. 
- 1978: Výzkum přemyslovského ústředí „castrum Zpytignew“ z 11. a 12. století a rekonstrukce jeho údělu v archeologických a písemných pramenech, AH 3, 183-215.

- 1981: Archeologický výzkum hradu „Rokyten“ na Moravě z 11. až první poloviny 12. století, jeho hradský obvod a románský dvorec Řeznovice - Die archäologische Untersuchung der Burg „Rokyten“ in Mähren aus dem 11.-12. Jh., ihr Sprengel und der romanische Herrenhof Řeznovice, AH 6, 221-238.

PARMA, D.-ŠPANIHEL, S., 2015: Moravský Krumlov (k. ú. Rokytná, okr. Znojmo), PV 56, no. 2, 291-292.

PETRÁČEK, T., 2012: Nevolníci a svobodní, kníže a velkostatek. Fenomén darovaných lidí přemyslovských zemí 10.-12. století. Praha.

- 2017: Power and Exploitation in the Czech Lands in the 10th-12th Centuries. A Central European Perspective. Leiden - Boston. https://doi.org/10.1163/9789004331495

PROCHÁZKA, R., 1985: Záchranný výzkum mladohradištního hradiska v Moravském Krumlově-Rokytné (okr. Znojmo), PV 1983, 50-51.

- 2009: Vývoj opevňovací techniky na Moravě a v českém Slezsku v raném středověku. Spisy Archeologického ústavu AV ČR Brno, v. v. i., 38. Brno.

- 2017: Hrad Přerov v raném středověku (9.-11. století) a počátky mladohradištní hmotné kultury. Brno.

- 2018: Přerov Stronghold and the Material Culture of Its Inhabitants in the Late Phase of the Early Middle Ages. In: Moravian and Silesian Strongholds of the Tenth and Eleventh Centuries in the Context of Central Europe Spisy Archeologického ústavu AV ČR 57 (Kouřil, P.-Procházka, R., edd.), 137-170. Brno.

PROCHÁZKA, R.-HLOŽEK, M.-ZÁVODNÁ, B., 2011: Doklady neželezné metalurgie ze sklonku 12. století z Brna, Josefská ulice, AR LXIII, 65-89.

PROCHÁZKA, R.-KOHOUTEK, J.-PEŠKA, J., 2007: Přerov Horní náměstí. Od Pravěkého hradiska ke středověkému městu. Archeologické památky střední Moravy 15. Olomouc.

PROCHÁZKA, R.-LOSKOTOVÁ, I., 1999: K topografii a interpretaci předlokačního osídlení brněnského historického jádra - Zur Topographie und Interpretation der Vorlokationsbesiedlung des brünner historischen Stadtkerns, AH 24, 169-188.

PROCHÁZKA, R.-PEŠKA, M., 2007: Základní rysy vývoje Brněnské keramiky ve 12.-13./14. století, PV 48, 143-232.

PROCHÁZKA, R.-WIHODA, M.-ZAPLETALOVÁ, D., 2011: V raném středověku. In: Dějiny Brna 1. Od pravěku k ranému středověku (Procházka, R., ed.), 447-560. Brno.

REYNOLDS, P., J., 1982: The ploughzone. In: Festschrift zum 100-jahriges Bestehen der Naturhistorischen Gesellschaft Nürnberg, 315-341. Nürnberg.

SCHMIDT, A. et al., 2016: Schmidt, A.-Linford, P.-Linford, N.-David, A.-Gaffney, C.-Sarris, A.-Fassbinder, J., EAC guidelines for the use of geophysics in archaeology: Questions to ask and points to consider, Europae Archaeologiae. Consilium guidelines 2. Namur.

ŠEBÁNEK, J.-DUŠKOVÁ, S., 1964: Česká listina doby přemyslovské (Nástin vývoje), SPFFBU C 11, 51-89.

ŠEBELA, L.-VANĚK, J., 1985: Hromadný nález ze studny v areálu bývalého bratrského sboru v Ivančicích. Přelom 16. a 17. století. Ivančice.

ŠLÉZAR, P., 2018: Olomouc between the Great Moravia and Přemyslid Duchies. In: Moravian and Silesian Strongholds of the Tenth and Eleventh Centuries in the Context of Central Europe. Spisy Archeologického ústavu AV ČR 57 (Kouřil, P.-Procházka, R., edd.), 115-135. Brno.

TRACHET, J. et al., 2017: Trachet, J.-Delefortrie, S.-Van Meirvenne, M.-Hillewaert, B.-De Clercq, A., Reassessing Surface Artefact Scatters. The Integration of Artefact-Accurate Fieldwalking with Geophysical Data at Medieval Harbour Sites Near Bruges (Belgium), Archaeological Prospection 24/2, 101-117. https://doi.org/10.1002/arp. 1552

WIHODA, M., 2010: Morava v době knížecí 906-1197. Česká historie 21. Praha.

ZAPLETALOVÁ, D., 2006: Staré Brno a brněnská předlokační aglomerace, AR LVIII, 758-771.

- 2017: Stav poznání raně středověkého hradu Brna, BMD 30, 11-56.

ŽEMLIČKA, J., 1998: „Dvacet pánư“ české země. K vymezení panujícího rodu v 11. a 12. století, ČMM CXVII, 293-309. 


\section{Shrnutí}

\section{Rokytná: nedestruktivní průzkum sídelní struktury raně sředověkého centra}

Ve srovnání s velkomoravskými centry 9.-10. století jsou naše poznatky o vzhledu moravských hradišt' z 11.-12. století poměrně strohé. Jejich výzkum je proto nejen důležitý, ale i potřebný. K takovým lokalitám se řadí také Rokytná, která spravovala vlastní hradský obvod a mezi přemyslovskými centry na Moravě zaujímá přední postavení. Hradisko se nachází v Oslavanské Brázdě, na ostrožně přístupné z jihu, která se tyčí nad stejnojmennou říčkou (obr. 1). Samotná ostrožna je rozdělena na dvě části. Jižní část - předhradí - o ploše asi 8,5 ha - má př́stupovou šíji o šířce zhruba $100 \mathrm{~m}$ a dnes se zde rozkládá obec Rokytná. Nezastavěná část tohoto prostoru nese název Malé Hradisko. Od zbytku ostrožny je pak druhou šijí, asi 130 m širokou, oddělena severní část Velké Hradisko. Plocha Velkého Hradiska zaujímá zhruba 3,5 ha a v současnosti jde o zemědělsky využívanou půdu. Centrum v Rokytné fungovalo v 11.-12. století v rámci Brněnského údělu a jeho zánik je spojován bud's výpravou českého knížete Vladislava II. proti moravským Přemyslovcům roku 1146, nebo s porážkou markraběte Konráda Oty knížetem Fridrichem v bitvě u Loděnice v roku 1185. Minulé archeologické výzkumy na hradišti nám poskytly základní informace o výskytu a typech objektů a jejich datování. Na akropoli byla zjištěna obvodová palisáda, dřevěná stavba $v$ těsné blízkosti valu a zahloubené chaty, $v$ jejichž dnech byly další jámy nepravidelného tvaru a otopná zařízení. Většina objektů byla datována do 11.-12. století, malá část také do středohradištního a pravěkého období. Vrcholně středověké objekty na akropoli chybí, jsou však doloženy v prostoru předhradí.

Úkolem prezentovaného výzkumu bylo rozšiřit naše poznatky o lokalitě aplikací nedestruktivních metod průzkumu, konkrétně kombinací povrchových sběrů a geofyzikální prospekce. Naše aktivity se zaměřily na akropoli, kde se podařilo prozkoumat přibližně 3,5 ha dostupné plochy. Na základě povrchových sběrů bylo možné vyčlenit tři základní skupiny (obr. 2, 3). Nejmladší skupinu (složka č. 1) tvořila tenkostěnná vrcholně středověká a novověká keramika, kterou lze datovat do 13.-20. století. Vyznačuje se jemnou a tvrdě pálenou hlínou. Do této kategorie lze zařadit 36 \% střepů. Nejvyšší koncentrace těchto střepů byla pozorována v okolí valu (v těsné blízkosti současné vesnice) a severovýchodní části akropole (v prostoru pod svahem). Další skupinu (složka č. 2) tvoří grafitová keramika, která chronologicky spadá do druhé poloviny 11. až 12 . století, tedy do doby existence hradiska. Do této kategorie lze zařadit 19 \% střepů. Materiál této složky je rozptýlen po celé ploše průzkumu. Sledovat můžeme také tři větší koncentrace: blízko jihozápadní hrany, podél šíjového valu a u severovýchodní hrany hradiska. Poslední skupinou (složka č. 3) je směs pravěkých a raně středověkých střepů, které však v naprosté většině případů nelze chronologicky bliže zařadit. Náleží do celé doby využívání lokality od neolitu po 12. století. Většina této složky spadá patrně také do doby existence hradiska, ovšem nedá se od staršího materiálu jednoznačně odlišit. V menší míře se v tomto nálezovém souboru vyskytují nálezy z 9.-10. století a pravěké zlomky. Do této kategorie lze zařadit $45 \%$ střepů, které rámcově kopírují rozptyl grafitové keramiky (složka č. 2).

Geofyzikální průzkum doložil přes 400 anomálií, které lze interpretovat jako potenciální archeologické objekty. V převážné většině jde o amorfní sídlištní jámy. V deseti až patnácti prŕpadech lze uvažovat o zahloubených chatách a osm anomálií je možné interpretovat jako pece. Jako celek vykazuje zástavba na hradisku určitou pravidelnost. Objekty jsou rozptýlené po celé ploše průzkumu poměrně rovnoměrně. Cesty, nebo pravidelné útvary, které bychom mohli označit jako dvorce, resp. hospodářské usedlosti, se nikde neprojevily. Podél severozápadního a severovýchodního obvodu hradiska byly zaznamenány propálené segmenty hradby (obr. 4, 5). Porovnání výsledků povrchových sběrů s výsledkem geofyzikálního průzkumu poukázalo na jeden základní trend: koncentrace grafitové a směsné keramické složky rámcově kopíruje výskyt objektů doložených geofyzikálním průzkumem (obr. 3:B, C, obr. 6). Výjimku tvoří skupina u severovýchodního okraje ostrožny, která zasahuje i do prostoru mezi dvěma 
koncentracemi detekovaných objektů. Zároveň se ale ukázalo, že koncentrace střepů neznamenají automaticky zvýšený počet archeologických objektů ve formě magnetických anomálíi. Shluky keramiky na lokalitě souvisí tedy z velké části s intenzitou narušování zahloubených objektů a postdepozičnými procesy. Ve střední části ostrožny je keramického materiálu méně. To koreluje s prázdným prostorem zjištěným při průzkumu magnetometrem. Tento jev lze vysvětlit patrně kombinací eroze a menší hustoty osídlení. Vzhledem k torzovitosti dochování archeologických objektů je řešení otázek týkajících se struktury osídlení problematické. Pokud však přijmeme předpoklad, že z důvodu hluboké orby a eroze se původní objekty zachovaly pouze torzovitě, odpovídá hustota geofyzikálně detekovaných objektů situaci konstatované během archeologických výzkumů Borise Novotného (1975).

Tento článek je výstupem výzkumu podporovaného Grantovou agenturou ČR, grant č. 18-16153S „Raně středověká hradiska ve světle nedestruktivního výzkumu“.

doc. Dr. phil. Peter Milo, Ústav archeologie a muzeologie Filozofické fakulty Masarykovy univerzity, Arna Nováka 1,60200 Brno, Česká republika,peter.milo@mail.muni.cz

Bc. Jan Havelka, Ústav archeologie a muzeologie Filozofické fakulty Masarykovy univerzity, Arna Nováka 1,602 00 Brno, Česká republika, jhavelka@mail.muni.cz 
